\title{
Chemoenzymatic synthesis and biological evaluation of enantiomerically enriched 1 -( $\beta$-hydroxypropyl)imidazolium- and triazolium-based ionic liquids
}

Paweł Borowiecki, Małgorzata Milner-Krawczyk and Jan Plenkiewicz

\section{Full Research Paper}

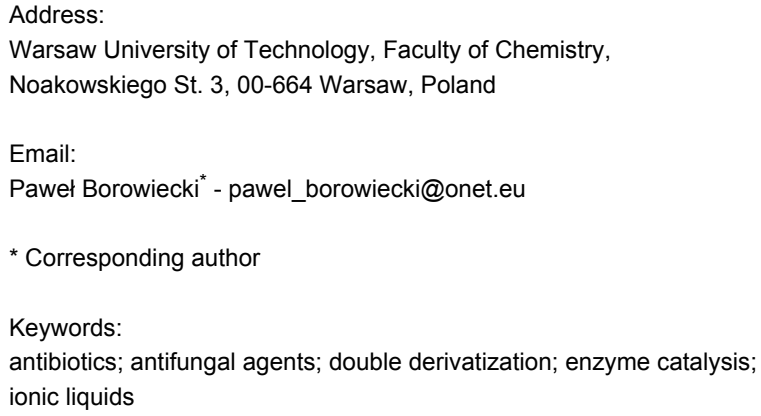

\author{
Beilstein J. Org. Chem. 2013, 9, 516-525. \\ doi:10.3762/bjoc.9.56 \\ Received: 30 November 2012 \\ Accepted: 15 February 2013 \\ Published: 12 March 2013 \\ Associate Editor: J. N. Johnston \\ (C) 2013 Borowiecki et al; licensee Beilstein-Institut. \\ License and terms: see end of document.
}

\begin{abstract}
Racemic 1-( $\beta$-hydroxypropyl)azoles were prepared by solvent-free direct regioselective ring opening of 1,2-propylene oxide with imidazole or 1,2,4-triazole. Lipase-catalyzed transesterification of alcohols with vinyl acetate resulted in kinetic enantiomers resolution. Separated $(S)$-enantiomers of (+)-1-(1H-imidazol-1-yl)propan-2-ol and (+)-1-(1H-1,2,4-triazol-1-yl)propan-2-ol were quaternized with alkyl bromides or iodides, yielding novel optically active ionic liquids. Racemic salts were tested against a wide range of microorganisms.
\end{abstract}

\section{Introduction}

Aromatic heterocycles play a crucial role in medicinal chemistry $[1,2]$. More than half of all known drugs contain at least one heterocyclic component. Novel biologically active compounds are often designed as analogues of endogenous ligands that are vital to biochemical processes. Since most of these substances are comprised of heterocycles, such rings by default become core structures of the newly designed therapeutically active compounds.

Many biomolecules (e.g., vitamins, amino acids, purines, alkaloids) containing an imidazole ring [3-5] meet the relevant bio- logical requirements, therefore, its presence in active substances is very desirable. Imidazole rings are also frequently present in antibacterial [6-8], antifungal [9-13], antiparasitic [14,15], anticancer $[16,17]$ and antiaggregatory $[18]$ preparations.

In turn, many 1,2,4-triazole derivatives exhibit antimicrobial [19,20], antifungal [21], antitumor [22], analgesic [23], antiinflammatory [24], psychoactive [25-27], anticonvulsant [28], diuretic [29], and anti-HIV [30] activity. 1,2,4-Triazole derivatives also represent the most important group of herbicides and fungicides [31]. 
In recent years growing attention has been focused on imidazole- and 1,2,4-triazole-derived ionic liquids (ILs), as well as their chiral derivatives (CILs). CILs have become a subject of intensive study since their potential as catalysts for asymmetric induction [32-34], as supplements for influencing reaction stereoselectivity [35], as chiral solvents in stereoselective polymerization [36], as chiral phase for gas chromatography [37], or as chiral differentiating solvents for spectroscopic investigations $[38,39]$ is far from being exhausted. CILs can also act as a tool for organizing the structure of solid polymeric electrolytes (SPE), playing the triple role as plasticizer, solvent for the ions, and medium. Most of the described optically active ILs are prepared from easily accessible natural chiral substrates [40]. The use of ILs in so-called "green chemistry", as for example solvents in inorganic or organic syntheses or as a replacement for many hazardous and volatile organic solvents, raises the question about the toxicity of newly designed compounds. Therefore, it is crucial to select the least toxic ILs with good chemical properties that can be used in industrial processes [41]. Moreover, a number of current studies have demonstrated the potential of certain ionic liquids to exhibit excellent antimicrobial activity, raising the possibility that ionic liquids could find application as biocidal agents in the control of microorganism growth [42-45].

Herein, we report the results of our investigation on the chemoenzymatic synthesis of new chiral ionic liquids using enzyme-catalyzed kinetic resolution of 1-( $\beta$-hydroxypro- pyl)azoles as a key step. We have shown that this attempt is simple and allows the preparation of new types of optically active ionic liquids. Inhibitory activity of the newly synthesized CILs was tested towards gram-negative and gram-positive bacteria and fungi.

\section{Results and Discussion Synthesis and enzymatic resolution of the $\mathrm{N}$-2-hydroxypropylazoles}

In this paper we report the synthesis of racemic 1-( $1 H$-imidazol1-yl)propan-2-ol and 1-(1H-1,2,4-triazol-1-yl)propan-2-ol and the procedure for lipase-catalyzed kinetic separation of their enantiomers. These enantiomers can be used as chiral synthons for new drugs, pesticides or task-specific ionic liquids. The 1-( $\beta$-hydroxypropyl)-imidazole ( \pm )-3a and -triazole $( \pm)$-3b used in this study were prepared as racemic mixtures according to the method described by Yus and co-workers [46] (Scheme 1). Next, these compounds were used as a new type of substrate in lipase-catalyzed transesterification, yielding both enantiomers with good optical purity.

The syntheses of the secondary alcohols $( \pm)-\mathbf{3 a}$ and $( \pm)$-3b were accomplished by the addition of imidazole (2a) or 1,2,4-triazole (2b) to 1,2-propylene oxide (1) under solvent-free conditions. The epoxide ring-opening reactions were carried for $24 \mathrm{~h}$ at elevated temperature $\left(32^{\circ} \mathrm{C}\right)$ and resulted in the formation of the appropriate alcohols $( \pm)-\mathbf{3 a}$ and $( \pm)$-3b in high yields (Scheme 1).

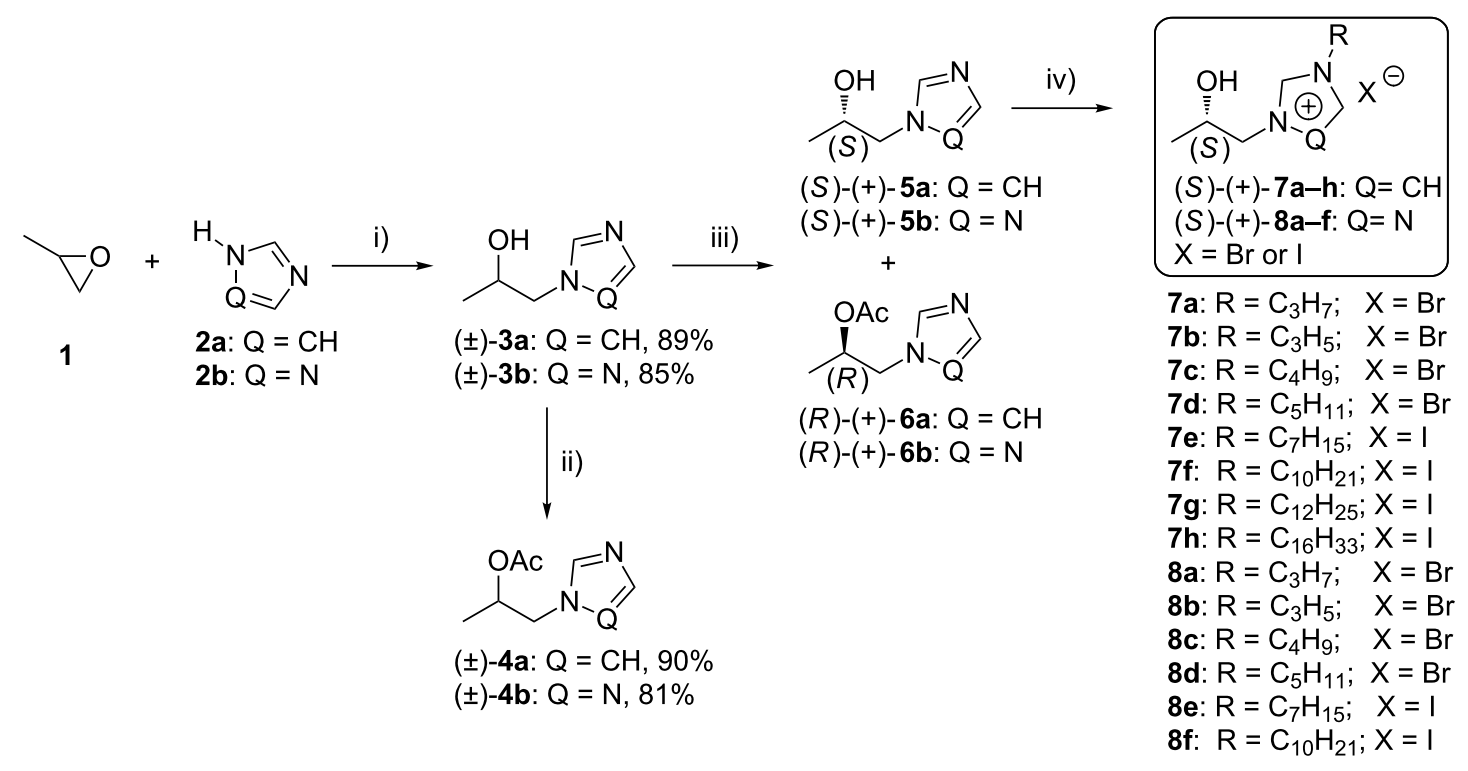

Scheme 1: Synthesis of optically active ILs. Reagents and conditions: (i) 1,2-propylene oxide ( 1.1 equiv), $32{ }^{\circ} \mathrm{C}, 24 \mathrm{~h}$; (ii) vinyl acetate (5 equiv), Novozyme SP 435, 2-methyl-2-butanol, rt, 48 h, magnetic stirrer; (iii) vinyl acetate (5 equiv), enzyme, 2-methyl-2-butanol/MTBE (methyl tert-butyl ether), rt, $250 \mathrm{rpm}$; (iv) $\mathrm{RX}$ (3 equiv), $\Delta$, dry $\mathrm{CH}_{3} \mathrm{CN}$. 
In the next step, the influence of crucial parameters in enzymecatalyzed reactions such as the type and quantity of the biocatalyst and solvent on the enantiomers resolution was investigated. The aim was to achieve a conversion close to $50 \%$ and $99 \%$ ee for the slow-reacting substrates and product enantiomers. Four different lipases, i.e., two native (Amano PS, Amano AK) and two immobilized enzymes (Novozym SP 435, Amano PS-IM), were chosen for the transesterification studies. The screenings were performed with a 5-fold molar excess of vinyl acetate as an irreversible acyl donor at ambient temperature. The selection of a proper solvent is a significant factor in biocatalysis $[47,48]$, since solvents are able to change the activity [49-51] and enantioselectivity [52-54] of an enzyme. Conformational changes in the enzyme structure under the influence of solvent can even invert the substrate specificity and the enzyme-substrate affinity [55]. The ability to control the direction of an enzymatic reaction and its specificity in a nonaqueous environment has resulted in the development of so-called "solvent engi- neering". After testing several solvents for lipase-catalyzed acetylation of $( \pm)$-3a and $( \pm)$-3b with vinyl acetate, we determined the following order of their utility as the reaction media: MTBE $\sim 2$-methyl-2-butanol $>$ acetone $>$ 1,4-dioxane $>>$ acetonitrile. Further optimization revealed that MTBE and 2-methyl2-butanol are unsurpassed, not only from the viewpoint of substrate solubility and reactivity, but also due to the highest enantiomeric excesses of the separated enantiomers. Results of the lipase-catalyzed transesterification of the racemic $( \pm)-\mathbf{3 a}$ are summarized in Table 1.

The experiments demonstrated that the reaction proceeded particularly efficiently when Amano AK or Amano PS-IM were used. These enzymatic preparations also gave excellent reaction enantioselectivities (Table 1, entries 3-5 and 11-13, E>> 200). Particularly, Amano AK was characterized by very high selectivity (Table 1 , entry $3, E=584$ ) toward the acetate $(+)-6 a$ formation, which was enantiomerically pure $(>99 \%$ ee) when

\begin{tabular}{|c|c|c|c|c|c|c|c|c|}
\hline Entry & Enzyme & Solvent & $t(\mathrm{~h})$ & Conv. $^{a}(\%)$ & Product & $\mathrm{ee}^{\mathrm{b}}(\%)$ & $E^{\mathrm{C}}$ & Yield $^{d}(\%)$ \\
\hline 1 & \multirow{2}{*}{ Amano PS } & MTBE $^{\mathrm{e}}$ & 20 & 30 & $\begin{array}{l}\text { alcohol } \\
\text { ester }\end{array}$ & $\begin{array}{l}41 \\
97\end{array}$ & 98 & $\begin{array}{l}95 \\
56\end{array}$ \\
\hline 2 & & 2-methyl-2-butanol & 26 & 32 & $\begin{array}{l}\text { alcohol } \\
\text { ester }\end{array}$ & $\begin{array}{l}46 \\
99\end{array}$ & 103 & $\begin{array}{l}43 \\
67\end{array}$ \\
\hline 3 & \multirow{3}{*}{ Amano AK } & MTBE $^{\mathrm{e}}$ & 5 & 47 & $\begin{array}{l}\text { alcohol } \\
\text { ester }\end{array}$ & $\begin{array}{r}88 \\
>99\end{array}$ & 584 & $\begin{array}{l}97 \\
62\end{array}$ \\
\hline 4 & & 2-methyl-2-butanole & 22 & 41 & $\begin{array}{l}\text { alcohol } \\
\text { ester }\end{array}$ & $\begin{array}{r}70 \\
>99\end{array}$ & 419 & $\begin{array}{l}95 \\
90\end{array}$ \\
\hline 5 & & 2-methyl-2-butanol ${ }^{f}$ & 43 & 45 & $\begin{array}{l}\text { alcohol } \\
\text { ester }\end{array}$ & $\begin{array}{r}80 \\
>99\end{array}$ & 492 & $\begin{array}{l}94 \\
91\end{array}$ \\
\hline 6 & \multirow{5}{*}{ Novozym SP 435} & MTBE $^{\mathrm{e}}$ & 1.5 & 57 & $\begin{array}{l}\text { alcohol } \\
\text { ester }\end{array}$ & $\begin{array}{l}97 \\
73\end{array}$ & 26 & $\begin{array}{l}95 \\
79\end{array}$ \\
\hline 7 & & MTBE $^{f}$ & 7 & 59 & $\begin{array}{l}\text { alcohol } \\
\text { ester }\end{array}$ & $\begin{array}{l}98 \\
68\end{array}$ & 23 & $\begin{array}{l}53 \\
73\end{array}$ \\
\hline 8 & & 2-methyl-2-butanol ${ }^{\mathrm{e}}$ & 7 & 30 & $\begin{array}{l}\text { alcohol } \\
\text { ester }\end{array}$ & $\begin{array}{l}40 \\
93\end{array}$ & 41 & $\begin{array}{l}99 \\
64\end{array}$ \\
\hline 9 & & 2-methyl-2-butanol ${ }^{f}$ & 11 & 53 & $\begin{array}{l}\text { alcohol } \\
\text { ester }\end{array}$ & $\begin{array}{l}82 \\
73\end{array}$ & 16 & $\begin{array}{l}70 \\
62\end{array}$ \\
\hline 10 & & 2-methyl-2-butanolf & 12 & 57 & $\begin{array}{l}\text { alcohol } \\
\text { ester }\end{array}$ & $\begin{array}{l}92 \\
68\end{array}$ & 17 & $\begin{array}{l}40 \\
60\end{array}$ \\
\hline 11 & \multirow{3}{*}{ Amano PS-IM } & MTBE $^{f}$ & 3 & 39 & $\begin{array}{l}\text { alcohol } \\
\text { ester }\end{array}$ & $\begin{array}{l}64 \\
99\end{array}$ & 386 & $\begin{array}{l}98 \\
75\end{array}$ \\
\hline 12 & & MTBE $^{f}$ & 4 & 46 & $\begin{array}{l}\text { alcohol } \\
\text { ester }\end{array}$ & $\begin{array}{l}82 \\
98\end{array}$ & 254 & $\begin{array}{l}66 \\
95\end{array}$ \\
\hline 13 & & 2-methyl-2-butanol ${ }^{f}$ & 5 & 38 & $\begin{array}{l}\text { alcohol } \\
\text { ester }\end{array}$ & $\begin{array}{r}60 \\
>99\end{array}$ & 368 & $\begin{array}{l}86 \\
88\end{array}$ \\
\hline
\end{tabular}

${ }^{a}$ Conversion was calculated from the enantiomeric excess of the starting material $\left(e_{\mathrm{s}}\right)$ and the product $($ ee $\mathrm{p})$ according to the formula: conv. $=$ $\mathrm{ee}_{\mathrm{s}} /\left(\mathrm{ee}_{\mathrm{s}}+\mathrm{ee}_{\mathrm{p}}\right)$. ${ }^{\mathrm{b}}$ Determined by HPLC analysis by using a Chiralcel OD-H column. ${ }^{\mathrm{c} C a l c u l a t e d}$ according to Chen et al. [56], by using the equation:

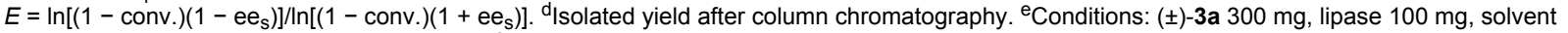
$3 \mathrm{ml}$, vinyl acetate $1 \mathrm{~g}$ (5 equiv), $250 \mathrm{rpm}$ at rt. ${ }^{\mathrm{f} C o n d i t i o n s: ~(~} \pm$ )-3a $300 \mathrm{mg}$, lipase $50 \mathrm{mg}$, solvent $3 \mathrm{ml}$, vinyl acetate $1 \mathrm{~g}$ (5 equiv), $250 \mathrm{rpm}$ at rt. 
the reaction was arrested close to $45 \%$ conversion. In turn, conversion exceeding $57 \%$ was beneficial for high optical purity of the remaining alcohol (+)-5a (Table 1, entries 6 and 7 , $>97 \%$ ee).

In the lipase-catalyzed acetylation of alcohol $( \pm)$-3b the best results were achieved with native Pseudomonas fluorescens lipase (Amano AK) suspended in 2-methyl-2-butanol (Table 2, entry $5, E=56$ ). As shown in the Table 2 , the reaction time required for about $50 \%$ substrate conversion varied from $5 \mathrm{~h}$ for Amano PS-IM in MTBE (Table 2, entry 8 ) to $132 \mathrm{~h}$ for the least active enzyme, i.e., native Amano PS in 2-methyl-2-butanol (Table 2, entry 2).

Generally, similar to acetylation of $( \pm)-\mathbf{3 a}$, the highest reaction rates for $( \pm)$-3b were observed with Amano PS-IM in MTBE. As usual, the optical purities of the acetate, as well as of the remaining alcohol, were dependent on the enzyme used and the conversion rate. For example, with Amano AK the reaction reached $37 \%$ conversion after $30 \mathrm{~h}$ giving product $(+)-6 \mathbf{b}$ in $90 \%$ ee (Table 2, entry 4 ), and after $49 \mathrm{~h}$ the stereochemical course reached $54 \%$ conversion yielding the slower reacting enantiomer $(+)-5 \mathbf{b}$ with high enantiomeric excess (Table 2, entry 5, 98\% ee). The highest optical purity for $(+)-6 \mathbf{b}(90 \%$ ee) and the shortest reaction time $(10 \mathrm{~h})$ were obtained by the reac- tion catalyzed by Amano PS-IM, which was much faster than that catalyzed by native Amano PS. The reaction enantioselectivities were fairly good $(E=20-56)$ for all of the tested lipases except Novozyme SP 435, which showed very high activity but low stereoselectivity $(E=6)$.

The racemic acetyl esters $( \pm)-\mathbf{4 a}$ and $( \pm)-\mathbf{4 b}$ used for determination of the enantiomeric configurations were prepared in good isolated yields by lipase-catalyzed esterification of the appropriate 1-( $\beta$-hydroxypropyl)azole $( \pm)$-3a or $( \pm)$-3b with vinyl acetate as the acyl donor (Scheme 1). The enzyme-catalyzed syntheses of acetylated standards were used, since the conventional esterification procedure of $\left( \pm\right.$ )-3a and $( \pm)-\mathbf{3 b}$ (with $\mathrm{Ac}_{2} \mathrm{O}$, pyridine and DMAP) gave low yields (ca. $25 \%$ ) of the acetates.

\section{Determination of the stereochemistry of alco- hols (+)-5a and (+)-5b}

The absolute configurations of the alcohols $(+)-\mathbf{5 a}$ and $(+)-\mathbf{5 b}$, obtained by lipase-catalyzed transesterification of the racemates $( \pm)-\mathbf{3 a}$ and $( \pm)-\mathbf{3 b}$, were determined by the modified Mosher's method as described by Riguera et al [57]. This approach consists of comparing the differences between ${ }^{1} \mathrm{H}$ NMR chemical shifts recorded for the diastereomeric esters prepared from the separated enantiomers of the alcohols $(+)-\mathbf{5 a}$ or $(+)-\mathbf{5 b}$ and $(R)$ - and $(S)$-enantiomers of methoxyphenylacetic acid

\begin{tabular}{|c|c|c|c|c|c|c|c|c|}
\hline Entry & Enzyme & Solvent & $t(\mathrm{~h})$ & Conv. $^{a}(\%)$ & Product & $\mathrm{ee}^{\mathrm{b}}(\%)$ & $E^{\mathrm{C}}$ & Yield $^{d}(\%)$ \\
\hline 1 & \multirow{2}{*}{ Amano PS } & MTBE $^{e}$ & 65 & 40 & $\begin{array}{l}\text { alcohol } \\
\text { ester }\end{array}$ & $\begin{array}{l}57 \\
84\end{array}$ & 20 & $\begin{array}{l}77 \\
87\end{array}$ \\
\hline 2 & & 2-methyl-2-butanole & 132 & 39 & $\begin{array}{l}\text { alcohol } \\
\text { ester }\end{array}$ & $\begin{array}{l}56 \\
88\end{array}$ & 27 & $\begin{array}{l}85 \\
73\end{array}$ \\
\hline 3 & \multirow{3}{*}{ Amano AK } & MTBE $^{e}$ & 12 & 41 & $\begin{array}{l}\text { alcohol } \\
\text { ester }\end{array}$ & $\begin{array}{l}63 \\
89\end{array}$ & 33 & $\begin{array}{l}97 \\
97\end{array}$ \\
\hline 4 & & 2-methyl-2-butanole & 30 & 37 & $\begin{array}{l}\text { alcohol } \\
\text { ester }\end{array}$ & $\begin{array}{l}54 \\
90\end{array}$ & 33 & $\begin{array}{l}93 \\
97\end{array}$ \\
\hline 5 & & 2-methyl-2-butanole & 49 & 54 & $\begin{array}{l}\text { alcohol } \\
\text { ester }\end{array}$ & $\begin{array}{l}98 \\
85\end{array}$ & 56 & $\begin{array}{l}93 \\
97\end{array}$ \\
\hline 6 & \multirow{2}{*}{$\begin{array}{l}\text { Novozym SP } \\
435\end{array}$} & MTBE $^{e}$ & 7 & 45 & $\begin{array}{l}\text { alcohol } \\
\text { ester }\end{array}$ & $\begin{array}{l}49 \\
59\end{array}$ & 6 & $\begin{array}{l}82 \\
98\end{array}$ \\
\hline 7 & & 2-methyl-2-butanole & 8 & 40 & $\begin{array}{l}\text { alcohol } \\
\text { ester }\end{array}$ & $\begin{array}{l}40 \\
60\end{array}$ & 6 & $\begin{array}{l}95 \\
93\end{array}$ \\
\hline 8 & \multirow{2}{*}{ Amano PS-IM } & MTBE $^{f}$ & 5 & 47 & $\begin{array}{l}\text { alcohol } \\
\text { ester }\end{array}$ & $\begin{array}{l}74 \\
84\end{array}$ & 25 & $\begin{array}{l}76 \\
87\end{array}$ \\
\hline 9 & & 2-methyl-2-butanol ${ }^{f}$ & 10 & 41 & $\begin{array}{l}\text { alcohol } \\
\text { ester }\end{array}$ & $\begin{array}{l}62 \\
90\end{array}$ & 36 & $\begin{array}{l}98 \\
77\end{array}$ \\
\hline
\end{tabular}

${ }^{a}$ Conversion was calculated from the enantiomeric excess of the starting material $\left(e_{s}\right)$ and the product $\left(e_{p}\right)$ according to the formula conv. $=$ $\mathrm{ee}_{\mathrm{s}} /\left(\mathrm{ee}_{\mathrm{s}}+\mathrm{ee}_{\mathrm{p}}\right) \cdot{ }^{\mathrm{b}}$ Determined by HPLC analysis by using Chiralcel OD-H column. ${ }^{\mathrm{C} C a l c u l a t e d}$ according to Chen et al. [56], by using the equation:

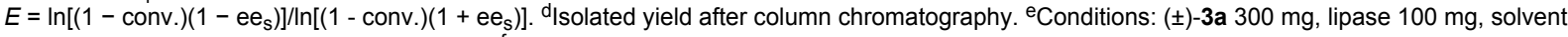
$3 \mathrm{ml}$, vinyl acetate $1 \mathrm{~g}$ (5 equiv), $250 \mathrm{rpm}$ at rt. ${ }^{\mathrm{f} C o n d i t i o n s: ~(~} \pm$ )-3a $300 \mathrm{mg}$, lipase $50 \mathrm{mg}$, solvent $3 \mathrm{ml}$, vinyl acetate $1 \mathrm{~g}(5 \mathrm{equiv}), 250 \mathrm{rpm}$ at rt. 


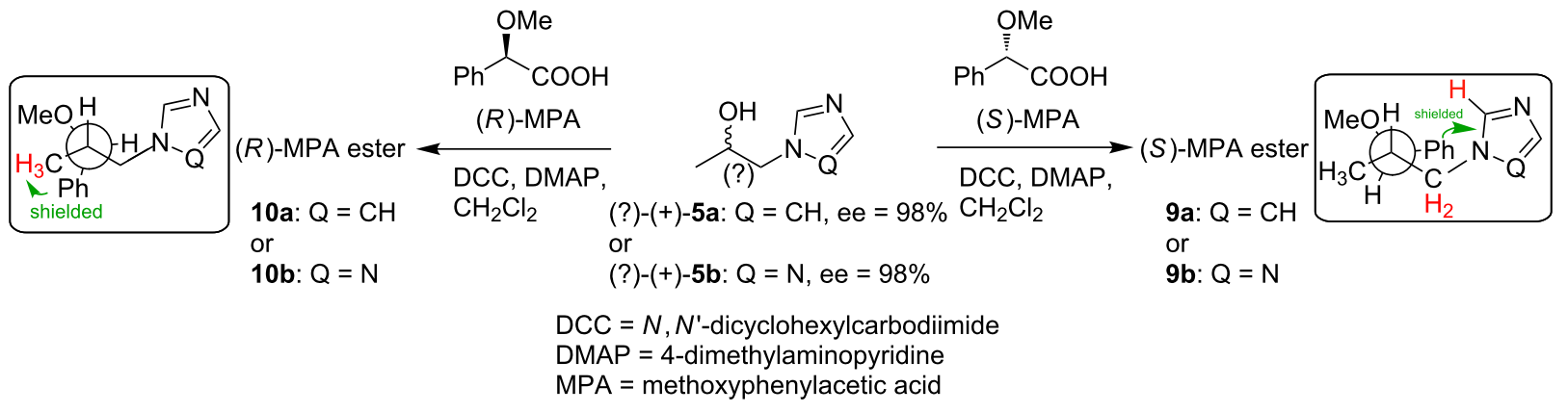

Scheme 2: Conversion of (+)-5a and (+)-5b into MPA esters $9 a, 9 b$ and $10 a, 10 b$.

(MPA, Mosher reagent) (Scheme 2). The utility of this method applied to secondary alcohols possessing heterocyclic azole rings has been demonstrated by us previously [58].

The absolute configuration of the substrate is deduced by interpretation of the signs of the $\Delta \delta^{R S}$ values, by using an empirical model that assumes that in MPA esters of secondary alcohols, the most representative conformer has the methoxy group of MPA, the carbonyl group, and a proton bonded to the stereogenic center of the alcohol in the same plane.

The differences in the chemical shifts $\left(\Delta \delta^{R S}\right)$ observed in the spectra of the esters prepared from the chiral auxiliaries $[(R)-$ and $(S)$-MPA acids, respectively], were calculated separately for the protons attached to the carbon atoms situated on both sides of the chirality center, as shown by the following equations:

$(+)-5 \mathbf{a}\left\{\begin{array}{l}\Delta \delta^{R S} \mathrm{~L}_{1}=\delta \mathrm{L}_{1}(R)-\delta \mathrm{L}_{1}(S)=7.36-6.45=+0.91>0 \\ \Delta \delta^{R S} \mathrm{~L}_{2}=\delta \mathrm{L}_{2}(R)-\delta \mathrm{L}_{2}(S)=1.10-1.19=-0.09<0\end{array}\right.$
$(+)-5 \mathbf{b}\left\{\begin{array}{l}\Delta \delta^{R S} \mathrm{~L}_{1}=\delta \mathrm{L}_{1}(R)-\delta \mathrm{L}_{1}(S)=7.89-7.28=+0.61>0 \\ \Delta \delta^{R S} \mathrm{~L}_{2}=\delta \mathrm{L}_{2}(R)-\delta \mathrm{L}_{2}(S)=1.17-1.26=-0.09<0\end{array}\right.$

The signs of these parameters bear the information necessary for the configurational assignment, since they indicate the relative position of L1/L2, with respect to the anisotropic group (phenyl group of MPA). The positive value of $\Delta \delta^{R S}$, which corresponds to the signal of the protons of the substituent L1, and the negative sign for the protons L2 indicate an $(S)$-configuration for the enantiomers of both types of investigated alcohols $(+)-5 \mathbf{a}$ and $(+)-\mathbf{5 b}$ according to Figure 1 . The ${ }^{1} \mathrm{H}$ NMR spectra recorded for the resulting diastereomeric derivatives (Figure 2) confirmed the results of the above equations.

The chiral environment provided by the derivatizing agent (MPA) covalently associated with the respective alcohol leads

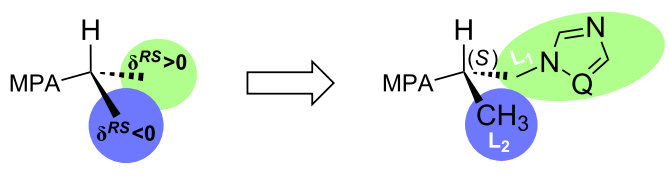

Figure 1: Model for the configurational correlation of MPA esters $9 a$, $9 \mathrm{~b}$ and $10 \mathrm{a}, 10 \mathrm{~b}$.

to significant differences in chemical shifts $(\delta=0.91 \mathrm{ppm})$, especially in the case of the imidazolium derivatives 9a and 10a. Comparison of the ${ }^{1} \mathrm{H}$ NMR spectra of these two species for this particular alcohol (+)-5a shows that the phenyl ring of the chiral auxiliary reagent projects its magnetic anisotropy strongly toward the $\mathrm{H}\left(2^{\prime}\right)$ proton in the $(S)$-derivative 9a, while the same proton in the $(R)$-MPA ester 10a remains unaffected. The opposite phenomenon is observed for methyl group protons $\mathrm{H}\left(8^{\prime}\right)$, which are shielded in (R)-MPA derivatives 10a due to the strength and direction of the anisotropic effect, while in $(S)$ MPA ester 9a they are unaffected. Similarly, information gained from ${ }^{1} \mathrm{H}$ NMR spectra of both species of triazolic alcohol, $9 \mathbf{b}$ and $\mathbf{1 0 b}$, defined (+)-5b as having $(S)$-configuration (see the lower part of the Figure 2).

\section{Synthesis of chiral ionic liquids}

In the final step, the appropriate chiral intermediates $(S)-(+)-1-$ (1H-imidazol-1-yl)propan-2-ol ((+)-5a) or $(S)-(+)-1-(1 H-1,2,4-$ triazol-1-yl)propan-2-ol ((+)-5b) and various alkyl halides were reacted in dry acetonitrile. The quaternization of the $\mathrm{N}-3$ atom of imidazole and that of $\mathrm{N}-4$ of the 1,2,4-triazole ring of the derivatives, provided salts $(+)-\mathbf{7} \mathbf{a}-\mathbf{h}$ and $(+)-\mathbf{8 a}-\mathbf{f}$ in $>81 \%$ and $>78 \%$ isolated yields, respectively (Table 3 ). With the exception of $(+)-\mathbf{8 a}-\mathbf{c}$ and $(+)-\mathbf{8} \mathbf{e}-\mathbf{f}$, which are exceedingly viscous liquids (gums), all of the chiral hydroxy-functionalized imidazolium and one of the triazolium salts are liquid at room temperature. Final products were characterized by ${ }^{1} \mathrm{H}$, ${ }^{13} \mathrm{C}$ NMR and FTIR spectroscopy as well as high-resolution 


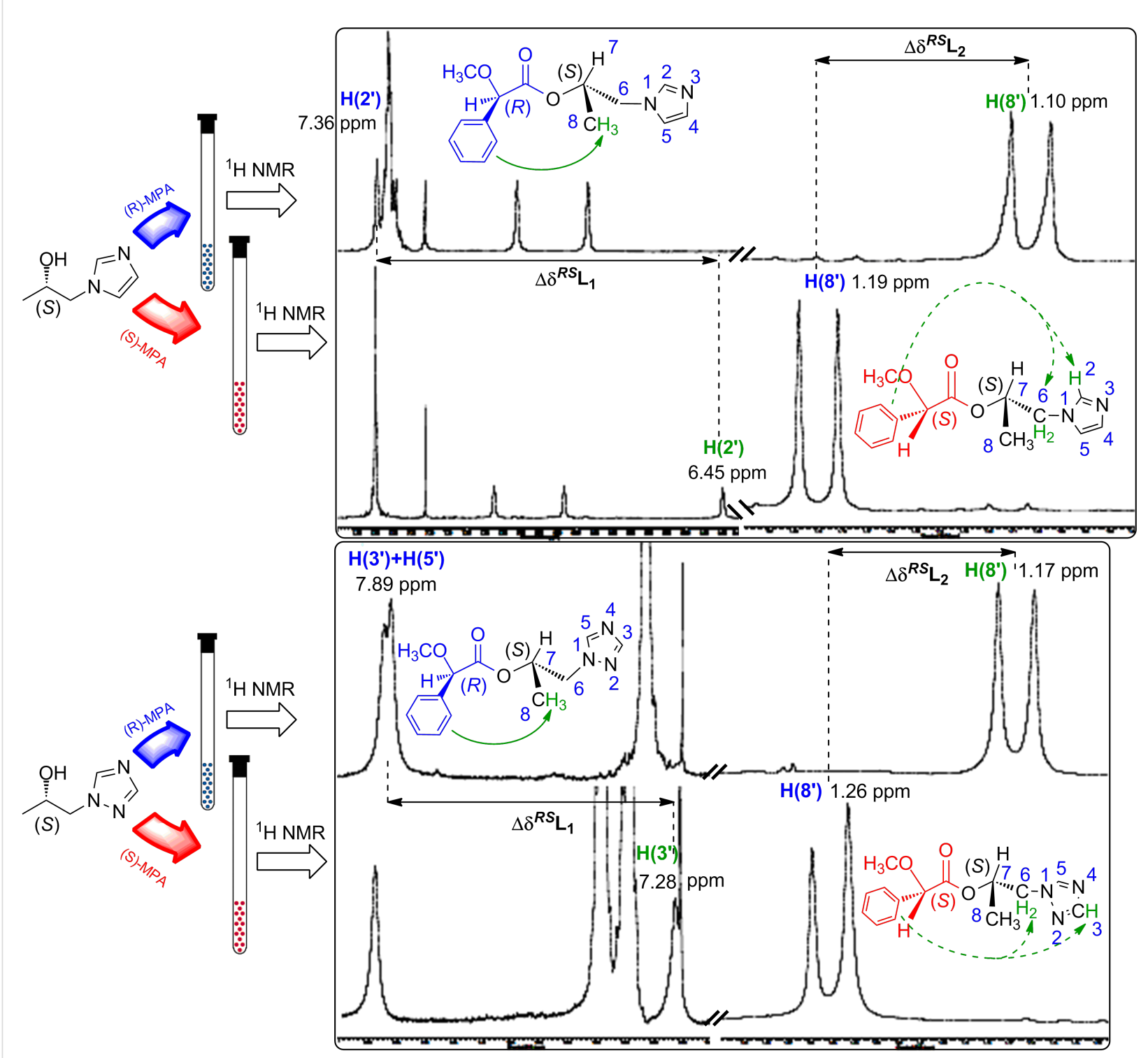

Figure 2: The ${ }^{1} \mathrm{H}$ NMR spectra of the derivatives of two unreacted chiral alcohols (+)-5a (top) and (+)-5b (bottom). Symbols marked in green represent protons shielded by the phenyl ring of chiral auxiliary (MPA); blue labels stand for unaffected protons.

electrospray ionization mass spectrometry (HRMS-ESI). Their structures were found to be spectroscopically well-defined, which was further confirmed by elemental analyses. For the purpose of biological tests, the racemic mixtures all of salts presented in Table 3 were synthesized.

\section{Antimicrobial activity of racemic ionic liquids}

Antibacterial and antifungal activities of the synthesized racemic CILs were evaluated against a wide range of microorganisms. The studies were conducted on three strains of gramnegative bacteria, two strains of gram-positive bacteria, and eight strains of fungi. For the preliminary screening of bacteria and yeasts we used the agar diffusion test (Table 4) in order to select the most promising compounds for further determination of minimal inhibitory concentrations (MICs) by the broth dilution method (Table 5). In turn, the antifungal activity was tested by the agar dilution method. The results are listed in Table 6 .

The antimicrobial and antifungal activities of tested CILs are significantly dependent on the alkyl chain length, as was demonstrated in numerous previous studies [59]. The high toxicity of CILs was noted for CILs with alkyl-chain substituents of 10-16 carbon atoms (Table 4 and 5). Moreover, the chemical nature of the cationic head group influenced the overall toxicity of the CILs, which is in good agreement with several previous studies [60]. The imidazolium CILs exhibited visibly stronger 


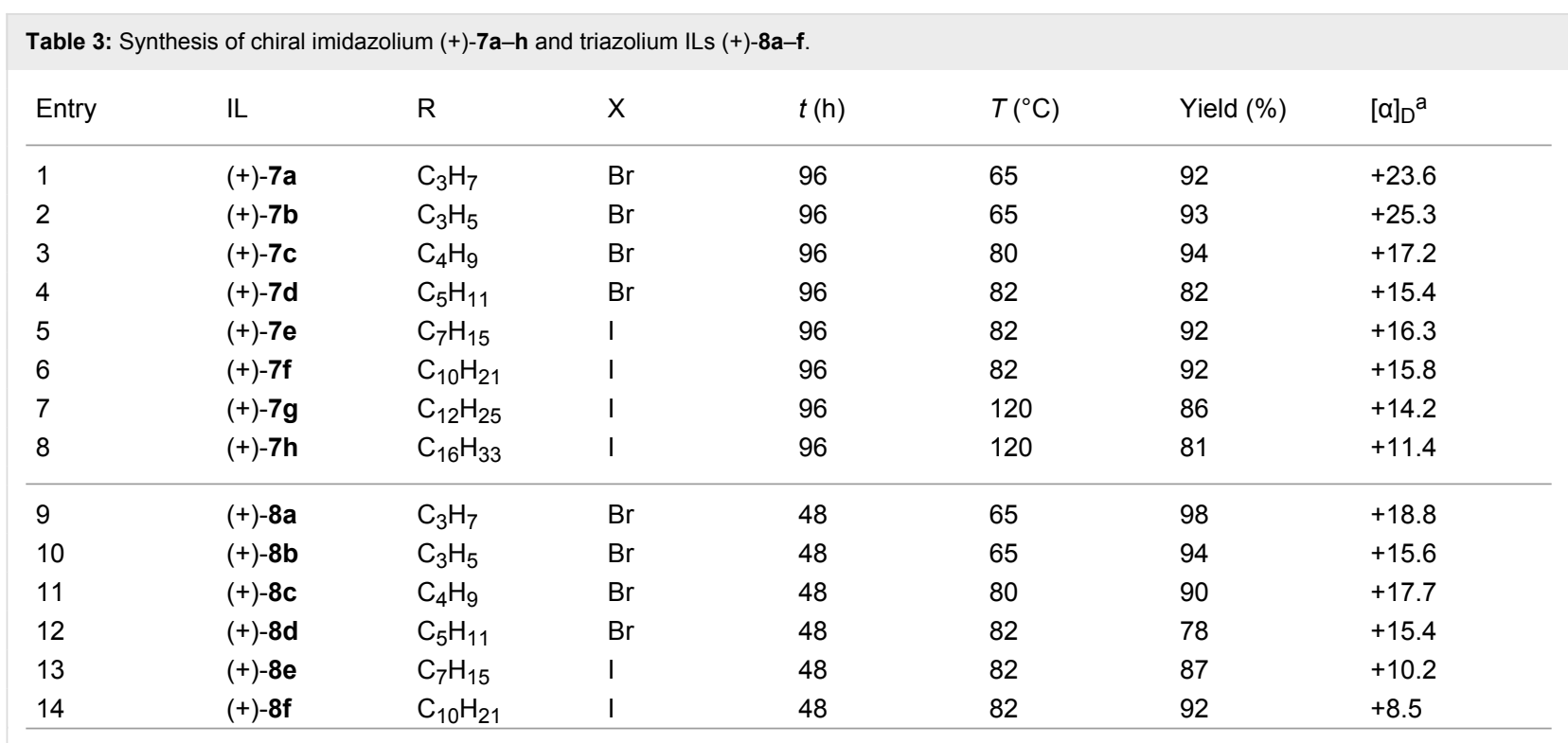

aspecific rotation; $c$ solution in chloroform (c 1.0).

Table 4: Growth inhibition halo $(\mathrm{cm})$ for the racemic imidazolium and triazolium CILs $(25 \mathrm{mM})$.

\begin{tabular}{|c|c|c|c|c|c|c|c|}
\hline CIL & $\mathrm{R}$ & $\begin{array}{l}\text { E. coli } \\
\text { ATCC } 8739 \\
\text { G(-) }\end{array}$ & $\begin{array}{l}\text { S. typhimurium } \\
\text { ATCC } 14028 \\
\text { G(-) }\end{array}$ & $\begin{array}{l}\text { P. aeruginosa } \\
\text { ATCC } 9027 \\
\text { G(-) }\end{array}$ & $\begin{array}{l}\text { B. subtilis } \\
\text { ATCC } 6633 \\
G(+)\end{array}$ & $\begin{array}{l}\text { S. aureus } \\
\text { ATCC } 6538 \\
G(+)\end{array}$ & $\begin{array}{l}\text { C. albicans } \\
\text { ATCC } 10231 \\
\text { yeast }\end{array}$ \\
\hline$( \pm)-7 a$ & $\mathrm{C}_{3} \mathrm{H}_{7}$ & - & - & - & - & - & - \\
\hline$( \pm)-7 d$ & $\mathrm{C}_{5} \mathrm{H}_{11}$ & - & - & - & - & - & - \\
\hline$( \pm)-7 e$ & $\mathrm{C}_{7} \mathrm{H}_{15}$ & $1.20 \pm 0.00$ & $1.03 \pm 0.04$ & $1.05 \pm 0.00$ & $1.20 \pm 0.00$ & $1.73 \pm 0.04$ & - \\
\hline$( \pm)-7 f$ & $\mathrm{C}_{10} \mathrm{H}_{21}$ & $1.40 \pm 0.00$ & $1.23 \pm 0.04$ & $1.10 \pm 0.00$ & $2.30 \pm 0.00$ & $2.80 \pm 0.00$ & + \\
\hline$( \pm)-8 \mathbf{a}$ & $\mathrm{C}_{3} \mathrm{H}_{7}$ & - & - & - & - & - & - \\
\hline$( \pm)-8 d$ & $\mathrm{C}_{5} \mathrm{H}_{11}$ & - & - & - & - & - & - \\
\hline$( \pm)-8 e$ & $\mathrm{C}_{7} \mathrm{H}_{15}$ & - & - & - & - & $1.00 \pm 0.00$ & - \\
\hline$( \pm)-8 f$ & $\mathrm{C}_{10} \mathrm{H}_{21}$ & $1.30 \pm 0.14$ & $1.25 \pm 0.07$ & $1.08 \pm 0.04$ & $1.90 \pm 0.14$ & $1.25 \pm 0.07$ & $1.18 \pm 0.04$ \\
\hline
\end{tabular}

-: No inhibition; +: total growth inhibition

Table 5: The MIC (mM) values for the racemic imidazolium and triazolium CILs.

\begin{tabular}{|c|c|c|c|c|c|c|c|}
\hline CIL & $\mathrm{R}$ & $\begin{array}{l}\text { E. coli } \\
\text { ATCC } 8739 \\
\mathrm{G}(-)\end{array}$ & $\begin{array}{l}\text { S. typhimurium } \\
\text { ATCC } 14028 \\
\mathrm{G}(-)\end{array}$ & $\begin{array}{l}P . \text { aeruginosa } \\
\text { ATCC } 9027 \\
G(-)\end{array}$ & $\begin{array}{l}\text { B. subtilis } \\
\text { ATCC } 6633 \\
\mathrm{G}(+)\end{array}$ & $\begin{array}{l}\text { S. aureus } \\
\text { ATCC } 6538 \\
\mathrm{G}(+)\end{array}$ & $\begin{array}{l}\text { C. albicans } \\
\text { ATCC } 10231 \\
\text { yeast }\end{array}$ \\
\hline$( \pm)-7 f$ & $\mathrm{C}_{10} \mathrm{H}_{21}$ & 0.5 & 0.4 & $>9.5$ & 0.5 & 0.2 & 0.3 \\
\hline$( \pm)-7 g$ & $\mathrm{C}_{12} \mathrm{H}_{25}$ & 0.3 & 0.5 & 1.6 & 0.5 & 0.3 & 0.1 \\
\hline$( \pm)-7 h$ & $\mathrm{C}_{16} \mathrm{H}_{33}$ & 0.2 & 0.5 & 9.0 & 0.2 & 0.3 & 0.3 \\
\hline$( \pm)-8 f$ & $\mathrm{C}_{10} \mathrm{H}_{21}$ & 1.7 & 4.8 & 5.5 & 3.0 & 0.5 & 0.9 \\
\hline
\end{tabular}

antibacterial and antifungal activity than triazolium CILs (Tables 4-6). However, the filamentous fungi displayed high tolerance towards the tested CILs. Nevertheless, the relation between the alkyl chain substituent and the antifungal activity of the tested compounds could still be observed, with the strongest toxicity demonstrated by CILs with an alkyl chain substituent of 12 carbon atoms (Table 6). This high tolerance of filamentous fungi against CILs could be explained by the ability 


\begin{tabular}{|c|c|c|c|c|c|c|c|c|}
\hline CIL & $\mathrm{R}$ & $\begin{array}{l}\text { F. oxysporum } \\
\text { MF } 5\end{array}$ & $\begin{array}{l}\text { F. sambucinum } \\
\text { MF } 1\end{array}$ & $\begin{array}{l}\text { F. culmorum } \\
\text { MF } 18\end{array}$ & $\begin{array}{l}\text { A. brasiliensis } \\
\text { ATCC } 16404\end{array}$ & $\begin{array}{l}\text { C. coccodis } \\
\text { MC } 1\end{array}$ & $\begin{array}{l}\text { P. infestans } \\
\text { MP } 324\end{array}$ & $\begin{array}{l}\text { P. infestans } \\
\text { MP } 1320\end{array}$ \\
\hline$( \pm)-7 a$ & $\mathrm{C}_{3} \mathrm{H}_{7}$ & $89.97 \pm 0.00$ & $99.60 \pm 0.88$ & $98.38 \pm 0.81$ & $100.78 \pm 0.78$ & $98.70 \pm 1.67$ & $98.81 \pm 3.76$ & $93.00 \pm 7.87$ \\
\hline$( \pm)-7 d$ & $\mathrm{C}_{5} \mathrm{H}_{11}$ & $90.12 \pm 5.10$ & $96.56 \pm 3.82$ & $101.32 \pm 1.02$ & $92.89 \pm 1.18$ & $96.71 \pm 1.58$ & $99.49 \pm 5.01$ & $104.17 \pm 7.04$ \\
\hline$( \pm)-7 e$ & $\mathrm{C}_{7} \mathrm{H}_{15}$ & $110.20 \pm 4.01$ & $87.55 \pm 8.03$ & $82.73 \pm 0.66$ & $89.92 \pm 5.47$ & $96.55 \pm 1.24$ & $90.65 \pm 2.14$ & $59.29 \pm 3.20$ \\
\hline$( \pm)-7 f$ & $\mathrm{C}_{10} \mathrm{H}_{21}$ & $59.70 \pm 5.12$ & $63.00 \pm 1.45$ & $68.40 \pm 1.00$ & $91.55 \pm 0.68$ & $99.54 \pm 1.76$ & $113.32 \pm 3.17$ & $99.43 \pm 4.21$ \\
\hline$( \pm)-7 g$ & $\mathrm{C}_{12} \mathrm{H}_{25}$ & $47.58 \pm 7.08$ & $61.33 \pm 1.50$ & $66.78 \pm 3.68$ & $87.20 \pm 0.72$ & $93.73 \pm 1.97$ & $88.21 \pm 6.76$ & $85.02 \pm 5.16$ \\
\hline$( \pm)-7 h$ & $\mathrm{C}_{16} \mathrm{H}_{33}$ & $74.35 \pm 11.65$ & $94.53 \pm 3.72$ & $74.13 \pm 8.51$ & $93.66 \pm 2.96$ & $103.10 \pm 45.34$ & $92.77 \pm 2.65$ & $91.87 \pm 2.28$ \\
\hline$( \pm)-8 a$ & $\mathrm{C}_{3} \mathrm{H}_{7}$ & $95.16 \pm 3.07$ & $102.28 \pm 0.76$ & $99.19 \pm 2.04$ & $98.40 \pm 3.45$ & $101.30 \pm 1.67$ & $101.58 \pm 2.37$ & $91.20 \pm 6.68$ \\
\hline$( \pm)-8 d$ & $\mathrm{C}_{5} \mathrm{H}_{11}$ & $94.65 \pm 3.43$ & $93.89 \pm 5.06$ & $105.29 \pm 2.64$ & $93.31 \pm 1.60$ & $97.53 \pm 6.64$ & $112.05 \pm 0.00$ & $93.05 \pm 24.81$ \\
\hline$( \pm)-8 e$ & $\mathrm{C}_{7} \mathrm{H}_{15}$ & $105.10 \pm 2.32$ & $98.39 \pm 5.47$ & $95.58 \pm 2.78$ & $104.12 \pm 1.58$ & $99.82 \pm 3.43$ & $104.63 \pm 7.64$ & $92.64 \pm 4.45$ \\
\hline$( \pm)-8 f$ & $\mathrm{C}_{10} \mathrm{H}_{21}$ & $77.35 \pm 5.95$ & $73.58 \pm 5.28$ & $92.64 \pm 7.14$ & $98.65 \pm 3.12$ & $104.59 \pm 2.59$ & $93.47 \pm 2.87$ & $95.58 \pm 4.82$ \\
\hline
\end{tabular}

of fungal cultures to change their cell biochemistry (resulting in an altered pattern of secondary metabolites) in response to CILs [61].

\section{Conclusion}

Lipase-catalyzed kinetic enantiomeric separation of 1-(1Himidazol-1-yl)propan-2-ol ( \pm )-3a proceeded with excellent enantioselectivity, exceeding $E=500$, in a short reaction time $(5 \mathrm{~h})$, by using a native enzymatic preparation from Pseudomonas fluorescens (Amano AK) as biocatalyst. In turn, after many trials we found that the kinetic separation of enantiomers of 1-(1H-1,2,4-triazol-1-yl)propan-2-ol ( \pm )-3b with various tested lipases was less efficient than that of $( \pm)-\mathbf{3 a}$. Resolution of $( \pm)$-3b proceeded with good yield, but the enantiomeric excess of the slower reacting enantiomer (alcohol (+)-5b) was less than $98 \%$. The faster reacting ester $(+)-\mathbf{6 b}$ barely reached $90 \%$ ee. Nevertheless, the procedure presented here is simple and efficient, and, after some additional optimization, can be readily extended to other substrates of this type. According to ${ }^{1} \mathrm{H}$ NMR investigations, the slower reacting enantiomers of the alcohols $(+)-\mathbf{5 a}$ and $(+)-\mathbf{5 b}$ possess $(S)$-configuration. This assignment is in good agreement with Kazlauskas's rule $[62,63]$, where in lipase-catalyzed esterification of secondary alcohols the $(R)$-ester and $(S)$-alcohol enantiomers are obtained. The imidazolic and triazolic chiral salts derived from alcohols (S)-(+)-5a and (S)-(+)-5b were obtained in high to excellent isolated yields. The core structures of these salts were modified by using, for quaternization reaction, haloalkanes or haloalkenes with various chain lengths. Their antibacterial and antifungal properties were evaluated by three different methods. Some of these compounds exhibited biological activity that was significantly dependent on the alkyl chain length, with considerably high toxicity of the substituents with $10-16$ carbon atoms. The imidazolium salts revealed stronger antibacterial activity than their triazolium analogues.

\section{Supporting Information}

\section{Supporting Information File 1}

Complete experimental procedures and characterization data.

[http://www.beilstein-journals.org/bjoc/content/

supplementary/1860-5397-9-56-S1.pdf]

\section{Acknowledgements}

The project was co-financed by The European Regional Development Fund under The Innovative Economy Operational Programme 2007-2013: "Biotransformations for Pharmaceutical and Cosmetic Industry” POIG.01.03.01-00-158/09. These studies were partially supported by the Warsaw University of Technology, Faculty of Chemistry. In addition, we would like to thank Dominika Brzezińska, M. Sc. for participating in the biological investigations.

\section{References}

1. Broughton, H. B.; Watson, I. A. J. Mol. Graphics Modell. 2004, 23, 51-58. doi:10.1016/j.jmgm.2004.03.016

2. Sperry, J. B.; Wright, D. L. Curr. Opin. Drug Discovery Dev. 2005, 8, 723-740.

3. Boiani, M.; Gonzalez, M. Mini-Rev. Med. Chem. 2005, 5, 409-424. doi:10.2174/1389557053544047

4. De Luca, L. Curr. Med. Chem. 2006, 13, 1-23. doi:10.2174/0929867310607010001

5. Du, H.; He, Y.; Sivappa, R.; Lovely, C. J. Synlett 2006, 965-992. doi:10.1055/s-2006-939720

6. Khabnadideh, S.; Rezaei, Z.; Khalafi-Nezhad, A.; Bahrinajafi, R.; Mohamadia, R.; Farrokhroz, A. A. Bioorg. Med. Chem. Lett. 2003, 13, 2863-2865. doi:10.1016/S0960-894X(03)00591-2

7. Khan, M. S.; Siddiqui, S. A.; Siddiqui, M. S. R. A.; Goswami, U.; Srinivasan, K. V.; Khan, M. I. Chem. Biol. Drug Des. 2008, 72, 197-204. doi:10.1111/j.1747-0285.2008.00691.x 
8. Atia, A. J. K. Molecules 2009, 14, 2431-2446. doi:10.3390/molecules14072431

9. Lennon, I. C.; Ramsden, J. A. Org. Process Res. Dev. 2005, 9, 110-112. doi:10.1021/op049838n

10. Rossello, A.; Bertini, S.; Lapucci, A.; Macchia, M.; Martinelli, A.; Rapposelli, S.; Herreros, E.; Macchia, B. J. Med. Chem. 2002, 45, 4903-4912. doi:10.1021/jm020980t

11. Hori, K.; Sakaguchi, A.; Kudoh, M.; Ishida, K.; Aoyama, Y.; Yoshida, Y. Chem. Pharm. Bull. 2000, 48, 60-64. doi:10.1248/cpb.48.60

12. Fringuelli, R.; Schiaffella, F.; Bistoni, F.; Pitzurra, L.; Vecchiarelli, A. Bioorg. Med. Chem. 1998, 6, 103-108. doi:10.1016/S0968-0896(97)10016-5

13. Norman, S. M.; Bennett, R. D.; Poling, S. M.; Maier, V. P.; Nelson, M. D. Plant Physiol. 1986, 80, 122-125. doi:10.1104/pp.80.1.122

14. Saadeh, H. A.; Mosleh, I. M.; El-Abadelah, M. M. Molecules 2009, 14, 2758-2767. doi:10.3390/molecules 14082758

15. Mukherjee, A.; Kumar, S.; Seth, M.; Bhaduri, A. P. Indian J. Chem., Sect. B: Org. Chem. Incl. Med. Chem. 1989, 28B, 391-396.

16. Bellina, F.; Cauteruccio, S.; Borsotti, P.; Taraboletti, G.; Monti, S.; Giavazzi, R.; Rossi, R. EJC Suppl. 2006, 4, 12-13. doi:10.1016/S1359-6349(06)70033-7

17. Bellina, F.; Cauteruccio, S.; Monti, S.; Rossi, R. Bioorg. Med. Chem. Lett. 2006, 16, 5757-5762. doi:10.1016/j.bmcl.2006.08.087

18. Manley, P. W.; Allanson, N. M.; Booth, R. F. G.; Buckle, P. E.; Kuzniar, E. J.; Lad, N.; Lai, S. M. F.; Lunt, D. O.; Tuffin, D. P. J. Med. Chem. 1987, 30, 1588-1595. doi:10.1021/jm00392a011

19. Castagnolo, D.; Radi, M.; Dessì, F.; Manetti, F.; Saddi, M.; Meleddu, R.; De Logu, A.; Botta, M. Bioorg. Med. Chem. Lett. 2009, 19, 2203-2205. doi:10.1016/j.bmcl.2009.02.101

20. Zhang, F.-F.; Gan, L.-L.; Zhou, C.-H. Bioorg. Med. Chem. Lett. 2010, 20, 1881-1884. doi:10.1016/j.bmcl.2010.01.159

21. Rezaei, Z.; Khabnadideh, S.; Pakshir, K.; Hossaini, Z.; Amiri, F.; Assadpour, E. Eur. J. Med. Chem. 2009, 44, 3064-3067. doi:10.1016/j.ejmech.2008.07.012

22. Villoutreix, B.; Reboud-Ravaux, M.; Basse, N.; Vidal, J.; Montes, M. Nitrogen heterocycle derivatives as proteasome modulators. WIPO Patent 2010/001365 A1, Jan 7, 2010.

23. Granberg, K.; Slassi, A.; Stefanac, T.; Wållberg, A. 1,2,4-Triazole carboxylic acid derivatives as modulators of mGluR5. WIPO Patent 2009/054787 A1, April 30, 2009.

24. Bryans, J. S.; Johnson, P. S.; Ryckmans, T.; Stobie, A. 3-Heterocyclyl-4-phenyl-triazole derivatives as inhibitors of the vasopressin V1a receptor. WIPO Patent 2005/105779 A1, Nov 10, 2005.

25. Walker, J. M.; Bowen, W. D.; Walker, F. O.; Matsumoto, R. R.; de Costa, B.; Rice, K. C. Pharmacol. Rev. 1990, 42, 355-402.

26. Jagerovic, N.; Cumella-Montanchez, J.; Goya-Laza, M.; Dordal Zueras, A.; Cuberes-Altisent, M. R. 1,2,4-Triazole derivatives as sigma receptor inhibitors. EP patent 1921073 A1, May 14, 2008. Also U.S. Patent 8,349,878 B2, Jan. 5, 2013.

27. Bonanomi, G.; Di Fabio, R.; Fazzolari, E.; Hamprecht, D.; Micheli, F.; Tarsi, L.; Terreni, S. Triazole derivatives as modulators of dopamine D3 receptors. WIPO Patent 2007/022933 A1, March 3, 2007.

28. Siddiqui, N.; Ahsan, W. Eur. J. Med. Chem. 2010, 45, 1536-1543. doi:10.1016/j.ejmech.2009.12.062
29. Shah, M. H.; Mhasalkar, M. Y.; Patki, V. M.; Deliwala, C. V.; Sheth, U. K. J. Pharm. Sci. 1969, 58, 1398-1401. doi:10.1002/jps.2600581123

30. Kirschberg, T. A.; Balakrishnan, M.; Huang, W.; Hluhanich, R.; Kutty, N.; Liclican, A. C.; McColl, D. J.; Squires, N. H.; Lansdon, E. B. Bioorg. Med. Chem. Lett. 2008, 18, 1131-1134. doi:10.1016/j.bmcl.2007.11.127

31. Yu, S.; Chai, X.; Hu, H.; Yan, Y.; Guan, Z.; Zou, Y.; Sun, Q.; Wu, Q. Eur. J. Med. Chem. 2010, 45, 4435-4445. doi:10.1016/j.ejmech.2010.07.002

32. Zhou, W.; Xu, L.-W.; Qiu, H.-Y.; Lai, G.-Q.; Xia, C.-G.; Jiang, J.-X. Helv. Chim. Acta 2008, 91, 53-59. doi:10.1002/hlca.200890012

33. Lee, J. W.; Shin, J. Y.; Chun, Y. S.; Jang, H. B.; Song, C. E.; Lee, S. Acc. Chem. Res. 2010, 43, 985-994. doi:10.1021/ar9002202

34. Hallett, J. P.; Welton, T. Chem. Rev. 2011, 111, 3508-3576. doi:10.1021/cr1003248

35. Shen, Z.-L.; Zhou, W.-J.; Liu, Y.-T.; Ji, S.-J.; Loh, T.-P. Green Chem. 2008, 10, 283-286. doi:10.1039/b717235d

36. Biedroń, T.; Kubisa, P. J. Polym. Sci., Part A: Polym. Chem. 2005, 43, 3454-3459. doi:10.1002/pola.20863

37. Rizvi, S. A. A.; Shamsi, S. A. Anal. Chem. 2006, 78, 7061-7069. doi:10.1021/ac060878u

38. Ni, B.; Zhang, Q.; Headley, A. D. Tetrahedron Lett. 2008, 49, 1249-1252. doi:10.1016/j.tetlet.2007.12.024

39. Joshi, M. D.; Anderson, J. L. RSC Adv. 2012, 2, 5470-5484. doi:10.1039/c2ra20142a

40. Poterała, M.; Plenkiewicz, J. Tetrahedron: Asymmetry 2011, 22 , 294-299. doi:10.1016/j.tetasy.2011.01.024

41. Wood, N.; Stephens, G. Phys. Chem. Chem. Phys. 2010, 12, 1670-1674. doi:10.1039/b923429b

42. Hough-Troutman, W. L.; Smiglak, M.; Griffin, S.; Reichert, W. M.; Mirska, I.; Jodynis-Liebert, J.; Adamska, T.; Nawrot, J.; Stasiewicz, M.; Rogers, R. D.; Pernak, J. New J. Chem. 2009, 33, 26-33. doi:10.1039/b813213p

43. Gilmore, B. F. Ionic Liquids: Applications and Perspectives. Kokorin, A., Ed.; InTech: New York, 2011; pp 587-604.

44. Ventura, S. P.; de Barros, R. L.; Sintra, T.; Soares, C. M.; Lima, A. S.; Coutinho, J. A. Ecotoxicol. Environ. Saf. 2012, 83, 55-62. doi:10.1016/j.ecoenv.2012.06.002

45. Paul, C. E.; Gotor-Fernández, V.; Lavandera, I.; Montejo-Bernardo, J.; García-Granda, S.; Gotor, V. RSC Adv. 2012, 2, 6455-6463. doi:10.1039/c2ra20876h

46. Torregrosa, R.; Pastor, I. M.; Yus, M. Tetrahedron 2007, 63, 469-473. doi:10.1016/j.tet.2006.10.055

47. Kinoshita, M.; Ohno, A. Tetrahedron 1996, 52, 5397-5406. doi:10.1016/0040-4020(96)00179-2

48. Herbst, D.; Peper, S.; Niemeyer, B. J. Biotechnol. 2012, 162, 398-403. doi:10.1016/j.jbiotec.2012.03.011

49. Burke, P. A.; Griffin, R. G.; Klibanov, A. M. Biotechnol. Bioeng. 1993, 42, 87-94. doi:10.1002/bit.260420112

50. Moniruzzaman, M.; Nakashima, K.; Kamiya, N.; Goto, M. Biochem. Eng. J. 2010, 48, 295-314. doi:10.1016/j.bej.2009.10.002

51. Yang, C.; Wang, F.; Lan, D.; Whiteley, C.; Yang, B.; Wang, Y. Process Biochem. 2012, 47, 533-537. doi:10.1016/j.procbio.2011.11.017

52. Margolin, A. L.; Tai, D. F.; Klibanov, A. M. J. Am. Chem. Soc. 1987, 109, 7885-7887. doi:10.1021/ja00259a049

53. Priego, J.; Ortíz-Nava, C.; Carrillo-Morales, M.; López-Munguía, A.; Escalante, J.; Castillo, E. Tetrahedron 2009, 65, 536-539. doi:10.1016/j.tet.2008.10.103 
54. Wang, J.; Sun, G.-X.; Yu, L.; Wu, F.-A.; Guo, X.-J. Bioresour. Technol. 2013, 128, 156-163. doi:10.1016/j.biortech.2012.10.098

55. Sakurai, T.; Margolin, A. L.; Russell, A. J.; Klibanov, A. M. J. Am. Chem. Soc. 1988, 110, 7236-7237. doi:10.1021/ja00229a061

56. Chen, C. S.; Fujimoto, Y.; Girdaukas, G.; Sih, C. J. J. Am. Chem. Soc. 1982, 104, 7294-7299. doi:10.1021/ja00389a064

57. Seco, J. M.; Quiñoá, E.; Riguera, R. Tetrahedron: Asymmetry 2001, 12, 2915-2925. doi:10.1016/S0957-4166(01)00508-0

58. Borowiecki, P.; Poterała, M.; Maurin, J.; Wielechowska, M.; Plenkiewicz, J. ARKIVOC 2012, No. viii, 262-281.

59. Carson, L.; Chau, P. K. W.; Earle, M. J.; Gilea, M. A.; Gilmore, B. F.; Gorman, S. P.; McCann, M. T.; Seddon, K. R. Green Chem. 2009, 11, 492-497. doi:10.1039/b821842k

60. Petkovic, M.; Seddon, K. R.; Rebelo, L. P. N.; Silva Pereira, C. Chem. Soc. Rev. 2011, 40, 1383-1403. doi:10.1039/c004968a

61. Petkovic, M.; Ferguson, J.; Bohn, A.; Trindade, J.; Martins, I.; Carvalho, M. B.; Leitão, M. C.; Rodrigues, C.; Garcia, H.; Ferreira, R.; Seddon, K. R.; Rebelo, L. P. N.; Silva Pereira, C. Green Chem. 2009, 11, 889-894. doi:10.1039/b823225c

62. Faber, K. Biotransformations in Organic Chemistry; Springer Verlag: Berlin, 1997; pp 90-91. doi:10.1007/978-3-662-00431-9

63. Kazlauskas, R. J.; Weissfloch, A. N. E.; Rappaport, A. T.; Cuccia, L. A J. Org. Chem. 1991, 56, 2656-2665. doi:10.1021/jo00008a016

\section{License and Terms}

This is an Open Access article under the terms of the Creative Commons Attribution License

(http://creativecommons.org/licenses/by/2.0), which permits unrestricted use, distribution, and reproduction in any medium, provided the original work is properly cited.

The license is subject to the Beilstein Journal of Organic Chemistry terms and conditions:

(http://www.beilstein-journals.org/bjoc)

The definitive version of this article is the electronic one which can be found at: doi:10.3762/bjoc. 9.56 